\title{
Effect of high hydrostatic pressure on antioxidant content of 'Ataulfo' mango during postharvest maturation
}

\author{
Viviana Guadalupe ORTEGA ${ }^{1}$, José Alberto RAMÍREZ², Gonzalo VELÁZQUEZ \\ Beatriz TOVAR ${ }^{1}$, Miguel MATA ${ }^{1}$, Efigenia MONTALVO ${ }^{1 *}$
}

\begin{abstract}
The objective of this study was to evaluate the effect of pressurization on the concentration of some antioxidant compounds and the antiradical efficiency during the ripening process of 'Ataulfo' mango. The fruits at physiological maturity stage were pressurized at 15, 30, or $60 \mathrm{MPa}$ for 10 or $20 \mathrm{~min}$. Control fruits were not pressurized. The fruits were stored at $25^{\circ} \mathrm{C}$ and changes in the concentration of ascorbic acid, total phenols, total flavonoids, total carotenoids, and antiradical efficiency were evaluated. It was demonstrated that in 'Ataulfo' mango high hydrostatic pressure treatments at 60 and $30 \mathrm{MPa}$ for 20 minutes induced the synthesis of ascorbic acid during storage maybe as a consequence of physiological changes and possible structural modification of the cells, while the fruits pressurized at $15 \mathrm{MPa}$ showed no effect on this parameter. On the other hand, the use of $15 \mathrm{MPa}$ for 10 minutes increased the synthesis of phenols, flavonoids, carotenoids, and antiradical efficiency in 'Ataulfo' mango compared to that of the control fruit. In conclusion, this behavior seemed to be due to the low hydrostatic pressure treatments $(15 \mathrm{Mpa})$, which stimulated the synthesis of antioxidants in the mango fruit and ripening was not inhibited.
\end{abstract}

Keywords: Mangifera indica L; high hydrostatic pressure; antioxidants.

\section{Introduction}

High hydrostatic pressure (HHP) is a relatively new, nonthermal food preservation process relatively new, which can inactivate or reduce the load of pathogenic microorganisms and inactivate deteriorative enzymes with a minimal effect on the overall quality of nutrients, color, and flavor in liquid or solid foods (GUERRERO; SWASON; BARBOSA, 2005). HHP is considered a non-thermal technology in the food industry because pressurization can be carried out at room temperature (KORHONEN et al., 1998).

HHP has been reported as an appropriated method to improve the extractability of bioactive compounds from vegetables and fruits. It has been demonstrated that the availability of lutein was higher in green beans pressurized at $600 \mathrm{MPa}$ than that of control samples or samples pressurized at $400 \mathrm{MPa}$. The effect seemed to be associated with the disruption of cellular structures during the pressure treatment. However, the use of HHP from 400 to $600 \mathrm{MPa}$ had very little impact on the availability of carotenoids and antioxidant capacity of either carrots or broccoli (McINERNEY et al., 2007). Using HHP improved the extraction of phenolic compounds of Rubus coreanus 'Miguel' fruits. An increase in the extraction was associated with alteration of the membrane cell permeability during pressurization, allowing the solvents to easily penetrate into the cytoplasm (YONG et al., 2011). HHP improved the extraction of bioactive compounds from 'Rojo Brillante' persimmon fruit at two stages of maturation. Samples treated at $400 \mathrm{MPa}$ showed higher extractability of compounds than the samples treated at $200 \mathrm{MPa}$ at these two stages of maturity. The improvement in extractability was associated with the cell wall rupture and dispersion of intracellular components through the tissue causing an overall decrease in firmness at both ripening stages (VÁZQUEZ-GUTIÉRREZ et al., 2011a).

Recently, HHP has been proposed as a quarantine treatment to destroy eggs and larvae of several genera and species of insects infesting raw fruits. However, preliminary reports have indicated that pressure levels required to destroy eggs and larvae of targeted pests (above $100 \mathrm{MPa}$ ) can induce detrimental changes in hosted fruits and modify their postharvest physiology (NEVEN; FOLLETT; RAGHUBEER, 2007; CANDELARIO et al., 2009; VELÁZQUEZ et al., 2010a, b). Consumers concerns regarding the nutritional quality and presence of bioactive compounds in fruits and vegetables has increased recently; therefore, the use of any postharvest technology in fruits and vegetables requires preserving their nutritional quality (WOLBANG; FITOS; TREEBY, 2008). On this regard, the effect of high pressure processing on changes in post-harvest physiology, nutritional composition, and overall quality of fruits requires further research.

Candelario et al. (2009) reported that HHP at $100 \mathrm{MPa}$ for $5 \mathrm{~min}$ in whole mango cv Tommy Atkins, showed minimal visible changes in fruit quality. On the other hand, 'Ataulfo' mangoes pressurized at 15 to $60 \mathrm{MPa}$ showed changes in their postharvest physiology, but their ripening process was not inhibited; the effect was dependent on the level of pressure,

\footnotetext{
Received 12/4/2013

Accepted 19/6/2013 (006063)

${ }^{1}$ Laboratorio Integral de Investigación en Alimentos - LIIA, Instituto Tecnológico de Tepic - ITT, Av. Tecnológico, 2595, CP 63175, Tepic, Nayarit, México, e-mail: efimontalvo@gmail.com

${ }^{2}$ Dirección General de Innovación Tecnológica, Centro de Excelencia, Universidad Autónoma de Tamaulipas - UAT, Ciudad Victoria, Tamaulipas, México

${ }^{3}$ Centro de Investigación en Ciencia Aplicada y Tecnología Avanzada - CICATA, Instituto Politécnico Nacional - IPN, Querétaro, Querétaro, México

${ }^{*}$ Corresponding author
}

DOI: http://dx.doi.org/10.1590/S0101-20612013005000062 
pressurization time, and interaction of both parameters (ÁLVAREZ-VIRRUETA et al., 2012). On the other hand, heat shock and UV-C irradiation have been reported as effective methods to induce abiotic stress in carrots, altering the respiratory metabolism and improving the synthesis of bioactive compounds (ALEGRIA et al., 2012). Nevertheless, information of using HHP to induce abiotic stress in fruits and vegetables to improve the synthesis of bioactive compounds is scarce.

The production of 'Ataulfo' mango in Mexico is important because it is one of the main varieties for export (MÉXICO, 2011). Currently, there have been scarce reports on the effect of HHP on the nutritional components of whole Ataulfo mango postharvest; therefore, the aim of this study was to evaluate the effect of HHP on changes in the concentration of different antioxidant compounds during postharvest maturation of 'Ataulfo' mango.

\section{Materials and methods}

\subsection{Plant material}

'Ataulfo' mangoes (Mangifera indica L) at physiological maturity were harvested in the 5 de Mayo Village in the municipality of Tepic Nayarit, Mexico. The fruits with the following characteristics were selected: light green color and sunk peduncle. The fruits were transported to the laboratory, washed, and immersed in a solution of 2-(4-thiazolyl)- $1 \mathrm{H}$ benzimidazole $(20 \mathrm{mg} / \mathrm{L})$ for 5 minutes to prevent fungal growth. Then they were dried and immediately used for this study. The fruits were pressurized on the harvest day (day 1) and stored at $25^{\circ} \mathrm{C}$ along with the control fruits. The response variables were measured starting on the second day of storage.

\subsection{High hydrostatic pressure treatment}

The mangoes were distributed into seven groups of 50 fruits per group. Each group was subjected to different pressure treatments: 15,30 , or $60 \mathrm{MPa}$ for 10 or 20 minutes at $25{ }^{\circ} \mathrm{C}$. A control group remained untreated. Hydrostatic pressure treatments were applied using an isostatic press; model CIP42260 (Avure Autoclave Systems, Erie PA USA) with a pressure chamber of $101.6 \mathrm{~mm}$ internal diameter and $584.2 \mathrm{~mm}$ in length, which operates at a maximum capacity of $400 \mathrm{MPa}$. A mixture of water and anticorrosive lubricant (diethyl-amino-ethanol; Hydrolubric 120-B, EF Houghton and Co., Valley Forge, PA) in 5:1 (v/v) ratio was used as a pressurizing fluid. The mixture temperature was adjusted to $25^{\circ} \mathrm{C}$ before pressurizing. The time required to reach the hydrostatic pressures of 15,30 , and $60 \mathrm{MPa}$ was 3,10 , and $28 \mathrm{~s}$, respectively. The time to release the pressure was always less than $20 \mathrm{~s}$. The pressurized fluid temperature was not higher than $26^{\circ} \mathrm{C}$ at the end of each treatment. The fruits were covered with high-density polyethylene and vacuum-sealed (Multivac model (100) at room temperature before introduced into the treatment chamber to avoid direct contact with the pressurizing liquid. Pressurized mangoes were stored at $25 \pm 1{ }^{\circ} \mathrm{C}$ and $85-90 \%$ relative humidity $(\mathrm{RH})$ until senescence.

\subsection{Ascorbic acid (AA)}

Ascorbic acid (AA) was analyzed using the technique reported by Suntornsuk et al. (2002); $10 \mathrm{~g}$ of mango pulp were homogenized with $25 \mathrm{~mL}$ of sulfuric acid $(2 \mathrm{~N}), 25 \mathrm{~mL}$ of distilled water, and $3 \mathrm{~mL}$ of starch used as indicator. The mixture was titrated with iodine $(0.05 \mathrm{~N})$, and the results were reported in $\mathrm{mg}$ ascorbic acid/100 $\mathrm{g}$ fresh weight (FW).

\subsection{Total carotenoids (TC)}

Two g of mango pulp were mixed with $7 \mathrm{~mL}$ of acetone:petroleum ether $80: 20(\mathrm{v} / \mathrm{v})$, and $0.5 \mathrm{~g}$ of $\mathrm{MgCO}_{3}$ were homogenized for $1 \mathrm{~min}$ before centrifuged at 15000 $\mathrm{rpm}$ for 30 minutes at $4{ }^{\circ} \mathrm{C}$. The supernatant was placed in a separator funnel adding $15 \mathrm{~mL}$ of $\mathrm{NaCl}(20 \%)$. The aqueous phase was drained, and the organic layer was diluted to 10 $\mathrm{mL}$ with petroleum ether. Absorbance was measured at $448 \mathrm{~nm}$ using a UV/Vis spectrophotometer (Jenway model 6705). The quantification was performed using a calibration curve of $\beta$-carotene (PHILIP; CHEN, 1988). To express $\beta$-carotene concentration on dry weight, the moisture content was measured in the mango pulp using the AOAC method (ASSOCIATION..., 1984).

\subsection{Extractable phenols (EP)}

$10 \mathrm{~g}$ of pulp were homogenized with $96 \%$ ethanol and sonicated (sonicator Cole-Parmer model 8891) for 30 minutes. Subsequently, the sample was centrifuged (centrifuge Hermle Labortechnick model Z36HK) at $11500 \mathrm{rpm}$ and $10{ }^{\circ} \mathrm{C}$ for 10 minutes. The supernatant was concentrated to a final volume of $4 \mathrm{~mL}$; then $5 \mathrm{~mL}$ Folin Ciocalteu's reagent and $20 \mathrm{~mL}$ of sodium bicarbonate $20 \%$ were added. The reaction was allowed to stand for 30 minutes, and absorbance was measured at $760 \mathrm{~nm}$ using a spectrophotometer. A calibration curve with standard chlorogenic acid was constructed to quantify the EP. The results were expressed as $\mathrm{mg}$ of chlorogenic acid/100 g dw (VIÑA; CHAVES, 2006).

\subsection{Total flavonoids (TF)}

The flavonoid extraction was performed as EP; $0.5 \mathrm{~mL}$ of extract was mixed with $3.1 \mathrm{~mL}$ of methanol and $0.15 \mathrm{~mL}$ of $\mathrm{NaNO}_{2}$ : water $(1: 20 \mathrm{w} / \mathrm{w})$; the reaction was carried out in complete darkness. After 5 and 6 minues, $0.15 \mathrm{~mL}$ of $\mathrm{AlCl}_{3}$ :water $(1: 10 \mathrm{w} / \mathrm{w})$ and $0.01 \mathrm{~mL}$ of $\mathrm{NaOH} 11.25 \mathrm{M}$ were added, respectively. The reaction was allowed to stand for $15 \mathrm{~min}$. Absorbance was measured at $415 \mathrm{~nm}$ using a spectrophotometer. The quantification was performed using a calibration curve with quercetin. The results were expressed as $\mathrm{mg}$ of quercetin/100 $\mathrm{g} \mathrm{dw}$ (ZHISHEN; MENGCHENG; JIANMING, 1999).

\subsection{Antiradical efficiency $(A E)$}

Antiradical efficiency was performed following the method of Sánchez-Moreno, Larrauri and Saura-Calixto (1998). To obtain the antioxidant extract, $5 \mathrm{~g}$ of pulp were stirred with $10 \mathrm{~mL}$ of absolute methanol for $2 \mathrm{~h}$ before centrifuged for 
30 minutes at $4{ }^{\circ} \mathrm{C}$ and $15000 \mathrm{rpm}$. A solution containing $25 \mathrm{mg} \mathrm{L}^{-1}$ of the radical 1, 1-diphenyl-2-picrylhydrazyl (DPPH.) was prepared. Portions of $5,10,20,30,40$, and $50 \mu \mathrm{l}$ of antioxidant extract were reacted separately with $3.5 \mathrm{~mL}$ of the DPPH.solution. Absorbance was measured at $515 \mathrm{~nm}$ every minute for 5 minutes using a spectrophotometer. Reduced $\mathrm{DPPH} \cdot$ was calculated over time with a calibration curve of this compound. The percentage of remaining DPPH per minutes was calculated using the following Equation 1:

$\% \mathrm{DPPH}{ }_{\text {remaining }}=\mathrm{DPPH} \cdot{ }_{\mathrm{T}} / \mathrm{DPPH} \cdot{ }_{\mathrm{T}=0}$

where: $\mathrm{DPPH} \cdot{ }_{\mathrm{T}}=$ Final concentration of DPPH. 1 to 5 minutes; $\mathrm{DPPH} \cdot{ }_{\mathrm{T}=0}=$ Initial concentration of DPPH.

The amount of antioxidant extract necessary to decrease the initial concentration of DPPH. $\left(\mathrm{EC}_{50}, \mathrm{~mL}\right.$ extract $/ \mathrm{kg}$ de $\mathrm{DPPH}$ ) to $50 \%$ was calculated plotting the $\% \mathrm{DPPH}$ remaining against microliters of extract, using a model fit to the data and calculating the amount of extract antioxidant that reduces by half DPPH. Time was plotted against microliters of antioxidant extract to get the time in min $\left(\mathrm{T}_{\mathrm{EC} 50}\right)$ needed to achieve the $\mathrm{EC}_{50}$. Finally, the antiradical efficiency (AE) was calculated using the following Equation 2

$\mathrm{EA}=1 / \mathrm{EC}_{50} * \mathrm{~T}_{\mathrm{EC} 50}$

\subsection{Statistical analysis}

Data were analyzed with a randomized complete block design with factorial $3 \times 2$ (pressure of 15,30 , and $60 \mathrm{MPa} \times$ time of 10 and 20 minutes), in which the blocks were the days of storage. Analysis of variance was carried out using the general linear model (GLM) of SAS (The SAS System for Windows, Version 6.11). Two replicates were performed, and each analysis was conducted in triplicate.

\section{Results and discussion}

\subsection{Ascorbic acid (AA)}

Figure 1 shows the AA content of control and pressurized fruits. The control mangoes showed an initial AA content of $134.98 \mathrm{mg} / 100 \mathrm{~g} \mathrm{FW}$ reaching a maximum of $149.14 \mathrm{mg} / 100 \mathrm{gFW}$ on day 11 , and then it decreased when the fruits were senescent. The content of ascorbic acid was similar to the previously reported values for 'Kent' mango (ROBLES-SÁNCHEZ et al., 2009).

The concentration of ascorbic acid in pressurized fruits was significantly affected $(\mathrm{P} \leq 0.05)$ by both factors: the level of pressure and the treatment time (Figure 1). ÁlvarezVirrueta et al. (2012) reported that 'Ataulfo' mango ripened after pressurization at $15 \mathrm{MPa}$ (10 and 20 minutes). Therefore, the ascorbic acid content in 'Ataulfo' mango after the $15 \mathrm{MPa}$ treatment was not affected. An increase in ascorbic acid during the first 8 days of storage was observed in all samples although it was evident that the highest pressure level and treatment time increased the ascorbic acid content more than the other treatments.
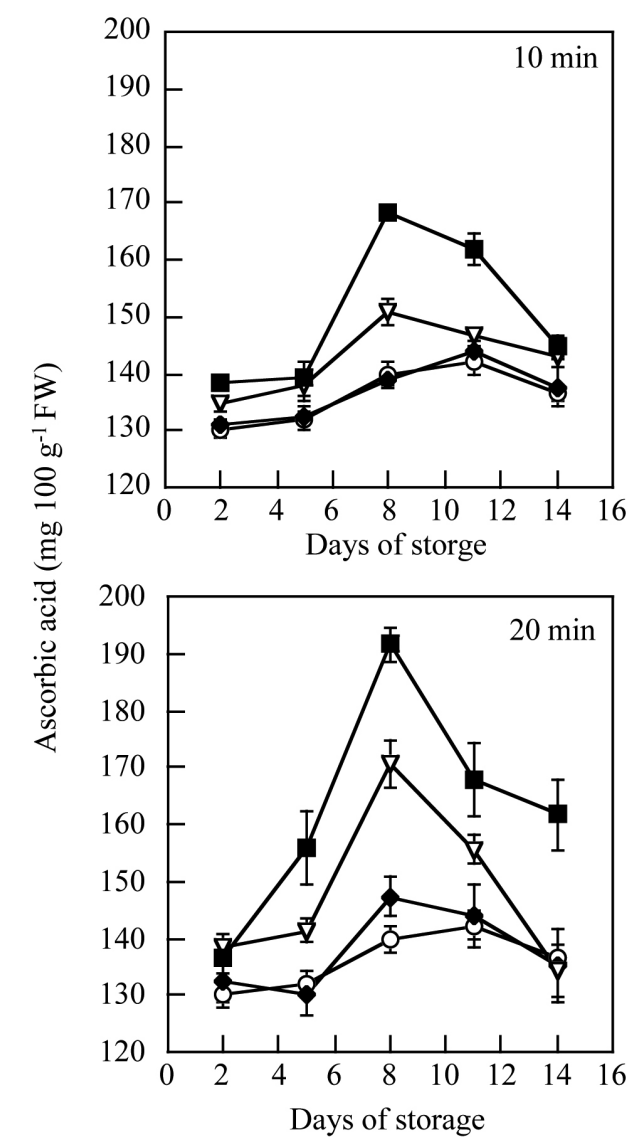

$\longrightarrow$ Control $\longrightarrow 15 \mathrm{Mpa} \longrightarrow-30 \mathrm{Mpa} \longrightarrow-60 \mathrm{Mpa}$

Figure 1. Effect of pressure treatments on the concentration of ascorbic acid during ripening of 'Ataulfo' mango stored at $25^{\circ} \mathrm{C}$.

In previous studies, 'Ataulfo' mango pressurized at $60 \mathrm{MPa}$ (10 or 20 minutes) showed lower respiration rate and ethylene production rate (ÁLVAREZ-VIRRUETA et al., 2012). Thus, an increase in ascorbic acid concentration in fruits pressurized at 30 and $60 \mathrm{MPa}$ might be associated with the structural alteration of the cells yielding a higher amount of extracted metabolite. Other possible explanation is that the higher concentration of ascorbic acid is a physiological response of the fruit to the stress conditions of higher pressurization levels. Eltelib et al. (2011) reported that the activity of monodehydroascorbate reductase and dehydroascorbate reductase, enzymes of the ascorbateglutathione cycle, was significantly up-regulated under stress conditions in Acerola (Malpighia glabra). On the other hand, it has been reported that pressurized mango and melon pulps showed changes in metabolites concentration associated with cell rupture (GUERRERO; SWASON; BARBOSA, 2005; WOLBANG; FITOS; TREEBY, 2008).

\subsection{Total carotenoids (TC)}

Changes in the concentration of total carotenoids during the ripening of control and pressurized fruits are shown in Figure 2. Control fruits showed a gradual increase in the content of total carotenoids during storage related to changes in the internal color, which is common during the ripening of the fruit. 
Total carotenoids in pressurized fruits were affected by the both factors: the level of pressure and the treatment time. Fruits pressurized for 10 minutes showed a higher level of total carotenoids with lower pressure levels $(\mathrm{P} \leq 0.05)$.
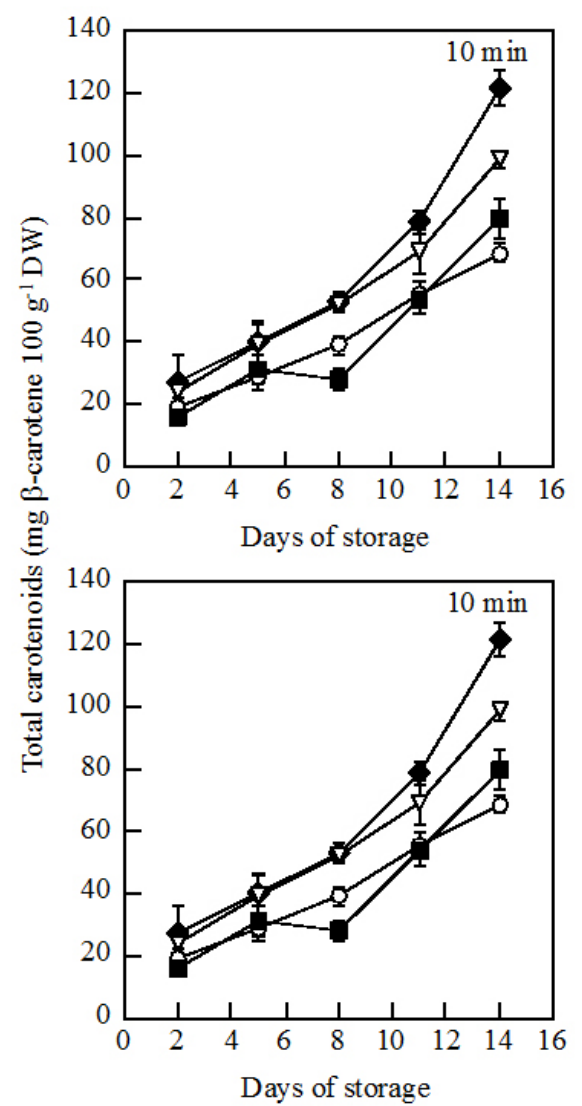

$$
\multimap-\text { Control } \longrightarrow 15 \mathrm{Mpa} \longrightarrow-30 \mathrm{Mpa} \longrightarrow-60 \mathrm{Mpa}
$$

Figure 2. Effect of pressure treatments on the concentration of total carotenoids during ripening of 'Ataulfo' mango stored at $25^{\circ} \mathrm{C}$.
Samples pressurized at 15 y $30 \mathrm{MPa}$ showed higher content of total carotenoids (121.22 and $98.67 \mathrm{mg} \beta$-carotene/100 g DW, respectively) than that of control samples $(68.65 \mathrm{mg}$ $\beta$-carotene/100 g DW) after 14 days of storage. Fruits pressurized for 20 minutes at 15 and $30 \mathrm{MPa}$ showed lower values of total carotenoids than that of fruits pressurized for 10 minutes. Mango pressurized at $60 \mathrm{MPa}$ for 10 or 20 minutes showed lower value of total carotenoids than that of control fruits (see Figure 3).

Similar results have been reported in persimmon fruit pressurized at $50 \mathrm{MPa}$, showing higher carotenoid content than that of fruits processed at higher level (>50 MPa) (DE ANCOS; GONZÁLEZ; CANO, 2000). The increased level of carotenes extracted from fruits as a result of high pressure has been reported in cultivars of melon (ROBLES-SÁNCHEZ et al., 2009) and persimmon fruits at maturity stages III and IV (PLAZA et al., 2012). The increasing in the extraction of carotenoids and other bioactive compounds due to high pressure level has been associated with cell wall disruption, inducing the intracellular component dispersion throughout the tissue (VÁZQUEZ-GUTIÉRREZ et al., 2011b). In 'Ataulfo' mango, the results indicate that the increase in total carotenoids at low levels of pressure (lower than $50 \mathrm{MPa}$ ) seems to be associated with an improvement in the synthesis of this metabolite and not with an improvement in the extraction of the pulp, usually caused by alterations in the cellular structure.

\subsection{Extractable phenols (EP)}

The effect of HHP on the extractable phenols is shown in Figure 4. Control fruits (non-pressurized) showed an initial content (day 2) of extractable phenols of $105.83 \mathrm{mg}$ of chlorogenic acid/100 g DW, which decreased after day 5 of storage, reaching a lower concentration of $63.53 \mathrm{mg}$ of chlorogenic acid/100 $\mathrm{g} \mathrm{dw}$ on day 14 , which means a decrease of $38 \%$ in the initial concentration of extractable phenols. This

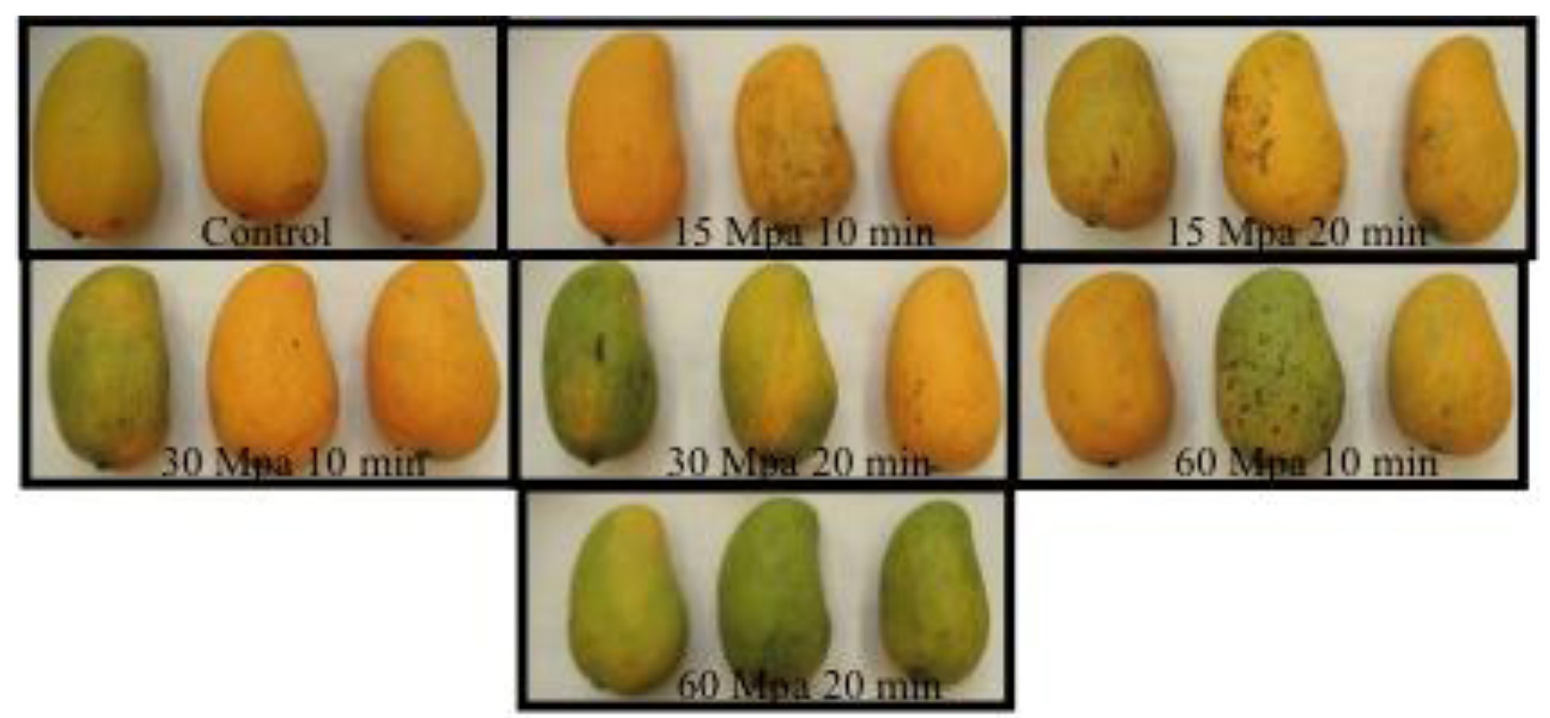

Figure 3. Visual effect of pressure treatments on 'Ataulfo' mango storage at $25^{\circ} \mathrm{C}$ for 14 days. 
behavior is characteristic of mango fruits since they contain a higher concentration of phenolic compounds at the unripe stage, decreasing their concentration during maturation (MASIBO; HE, 2008).

Mangoes pressurized at 15 or $30 \mathrm{MPa}$ showed a higher level of EP than that of control fruits after day 8 of storage. The level of EP was higher in mangoes pressurized at $15 \mathrm{MPa}$ than mango pressurized at $30 \mathrm{MPa}$; this behavior was more evident in mangoes pressurized for 10 minutes than fruits pressurized for 20 minutes, suggesting an improved response in the production of this antioxidant metabolites induced by pressurization. Phenolic compounds are antioxidant compounds synthesized to target the oxidative damage caused by the ripening of fruit or mechanical damage (GRASSMANN; HIPPELI; ELSTNER, 2002). The use of HHP in whole fruits is a physical phenomenon that can cause stress to the fruits and induce the synthesis of secondary metabolites.

Mangoes pressurized at $60 \mathrm{MPa}$ ( 10 or 20 minutes) showed a different behavior, with an initial increase in the level of EP on day 5 and a subsequent and gradual decrease during storage. The initial improvement in the content of EP might be associated to an increase in the synthesis of this metabolite as a response to the oxidative stress generated immediately after the high pressure treatments. However, the reduction in the content of EP in these fruits might be associated with damage in the cellular structures involved in the synthesis of this metabolite.
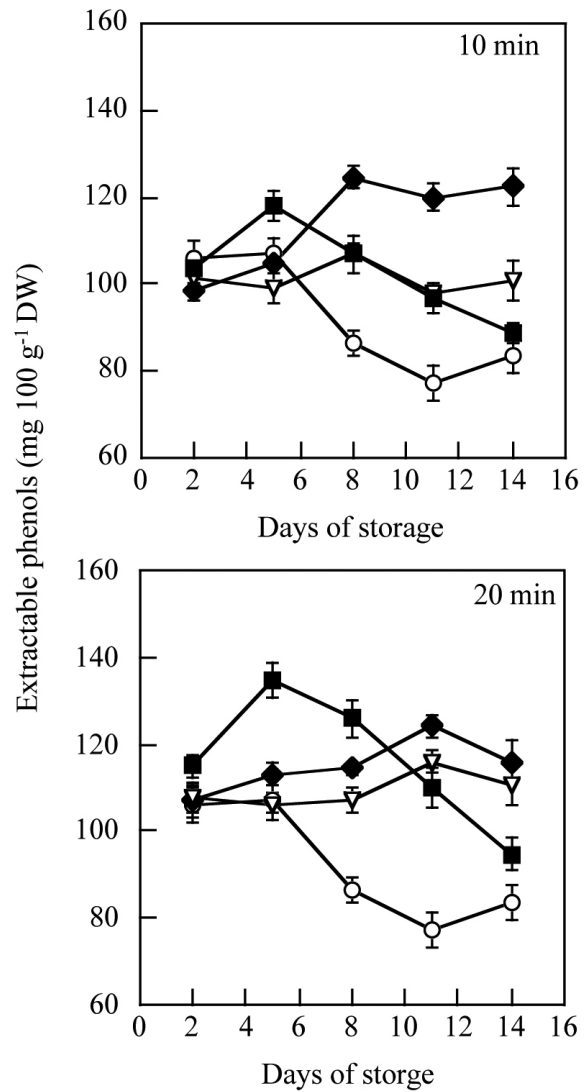

$\longrightarrow$ Control $\longrightarrow 15 \mathrm{Mpa} \longrightarrow 30 \mathrm{Mpa}$ $-60 \mathrm{Mpa}$

Figure 4. Effect of pressure treatments on the concentration of extractable polyphenols during ripening of 'Ataulfo' mango stored at $25^{\circ} \mathrm{C}$.
HHP has been reported as an effective method to improve the extraction of phenolic content in fruit products (juices, mousses) increasing the antioxidant activity (FERRARI; MARESCA; CICCARONE, 2011). The effect of HHP treatments has been studied on fresh-cut fruits, but not on whole fruit. In an experiment using high pressure combined with argon in freshcut apples stored at $4{ }^{\circ} \mathrm{C}$, it was found significantly reduction in the total phenolics content (WU; ZHANG; WANG, 2012). In the present study, the content of EP was higher at lower values of pressure, suggesting that $15 \mathrm{Mpa}$ had a positive effect on the synthesis of these bioactive compounds during the storage of whole fruits.

\subsection{Total flavonoids (TF)}

The effect of HHP on the content of TF is shown in Figure 5. The concentration of flavonoids in the control fruits reached the maximum level on day 5 and decreased gradually to reach the lowest level on day 14. This behavior has been previously reported in the literature. The flavonoid content of fruits increased or kept unchanged during ripening or storage, but during senescence, most flavonoids decreased (KEVERS et al., 2007).

Pressure levels affected the synthesis of flavonoids. On the first eight days, the synthesis of flavonoids was low and depended on the level of pressure, this means that at the lowest pressure,
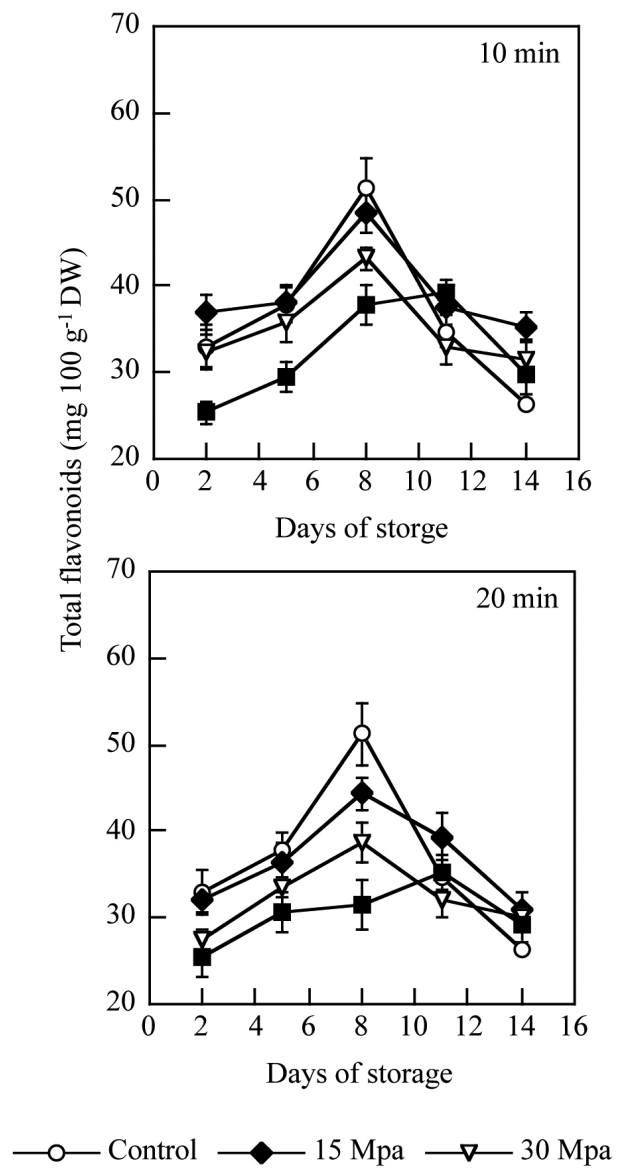
$60 \mathrm{Mpa}$

Figure 5. Effect of pressure treatments on the concentration of total flavonoids during ripening of 'Ataulfo' mango stored at $25^{\circ} \mathrm{C}$. 
the highest content of flavonoids synthesized and vice versa. On day 8 , the mangoes pressurized at $15 \mathrm{MPa}$ (10 or 20 minutes) showed the highest level of total flavonoids $(\mathrm{P} \leq 0.05)$. Different factors, including ultraviolet rays and physical alteration for HHP, can change the metabolism of polyphenols, including flavonoids inducing their synthesis or degradation (ABOUZID; ELSHERBEINY, 2008; SHIRLEY, 2002). In the present study, HHP affected the content of flavonoids during ripening, and this phenomenon could be associated with changes in the activity of enzymes involved in their synthesis although more research is needed to support this hypothesis. Menezes et al. (2008) reported that polyphenoloxidase activity was stimulated when acai pulp was subjected to $500 \mathrm{MPa}$ at $25^{\circ} \mathrm{C}$ (5 to 15 minutes) in comparison with the pulp pressurized to $300 \mathrm{MPa}$ under the same conditions. Additionally, HHP can damage the vegetable tissue inducing changes in the membrane permeability of cells, facilitating the contact of substrate and enzymes (TANGWONGCHAI; LEDWARD; AMES, 2000). Maybe the TF decrease is due to increased activity of polyphenoloxidase by the interaction of the enzyme with polyphenols.

\subsection{Antiradical efficiency (AE)}

The AE of control fruits decreased slightly after day 2 and increased gradually to reach its maximum level on day 14 (Figure 6). This behavior is consistent with the antioxidant capacity reported for 'Keitt' mango, which increased during ripening (TALCOTT et al., 2005). The antioxidant capacity reported for 'Ataulfo' mango in this study could be considered in the middle level of activity as compared with the capacity reported for other fruits (ZHISHEN; MENGCHENG; JIANMING, 1999).

Pressure treatments increased significantly $(P \leq 0.05)$ the $\mathrm{AE}$ of mango fruits compared to that of control fruits during ripening, depending on the level of pressure. Fruits pressurized at $15 \mathrm{MPa}$ showed higher levels of $\mathrm{AE}$ than fruits pressurized at 30 or $60 \mathrm{MPa}$ (Figure 6). This behavior was more evident when fruits were pressurized for 10 minutes than when they were pressurized for 20 minutes. Mangoes pressurized at $15 \mathrm{MPa}$ for 10 minutes reached its maximum level of $\mathrm{AE}$ on day 11, while mangoes pressurized at 30 and $60 \mathrm{MPa}$ reached their maximum $\mathrm{AE}$ on day 8 and remained lower than the value of fruits pressurized at $15 \mathrm{MPa}$.

The increase in antiradical efficiency of fruits could be associated to an increase in the synthesis of bioactive compounds and/or an increase in the extraction of bioactive compounds from the fruit pulp. As previously discussed, HPP can induce changes in the structure of fruit tissue and in the cell membrane permeability, resulting in the release of antioxidant compounds into the extracellular medium. However, an increase in the extractability of bioactive compounds is always dependent on a higher level of pressure (McINERNEY et al., 2007; GRASSMANN; HIPPELI; ELSTNER, 2002; VÁZQUEZGUTIÉRREZ et al., 2011a). In the present study, the increase in the concentration of bioactive compounds and antiradical efficiency seemed to depend on a lower level of pressure. This behavior indicates a physiological response associated to the

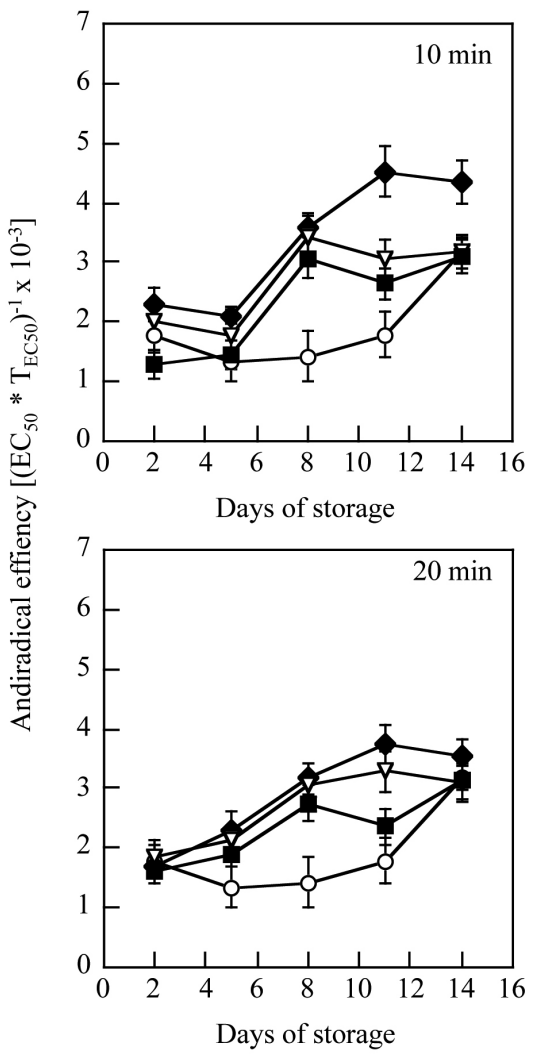

$\longrightarrow$ Control $\longrightarrow 15 \mathrm{Mpa} \longrightarrow-\mathbf{\nabla}-30 \mathrm{Mpa} \longrightarrow \mathbf{M p a}$

Figure 6. Effect of pressure treatments on the concentration of antiradical efficiency during ripening of 'Ataulfo' mango stored at $25^{\circ} \mathrm{C}$.

oxidative stress induced by external factors, which in this case were the high pressure treatments.

The increase in the antiradical efficiency of pressurized mango fruits (Figure 6) seemed to be highly dependent on the total carotenoids concentration (Figure 2). However, it is important to consider that $\mathrm{AE}$ depends not only on carotenoids, but also on other bioactive compounds present in the fruit. Kevers et al. (2007) reported a relationship between the antiradical efficiency and the phenolic content in different fruits, so it is possible that these compounds and carotenoids have a significant influence on the $\mathrm{AE}$ in fruits treated at $15 \mathrm{MPa}$.

\section{Conclusions}

High hydrostatic pressure caused changes in the content of antioxidants in 'Ataulfo' mango during postharvest ripening at $25^{\circ} \mathrm{C}$. The effect of HHP on mango fruits depended on the level of pressure and time of processing. The fruits treated with less pressure and time (15 MPa for 10 minutes) showed higher values of extractable phenols content, total carotenoids, total flavonoids, and antiradical efficiency than those of the control fruits during storage. 


\section{Acknowledgments}

The authors gratefully acknowledge the financial support of Programa de Mejoramiento del Profesorado (PROMEP) and CONACyT, México through the grant 237840. Publication of this article was funded by PIFI 2011-2012. The valuable donation of fresh mangoes for this research by Mr. Abelardo González Cabrera is truly appreciated.

\section{References}

ABOUZID, S. F.; ELSHERBEINY G. M. Increase in flavonoids content in red onion peel by mechanical shredding. Journal of Medicine Plants Research, v. 2, n. 9, p. 258-260, 2008.

ALEGRIA, C. et al. Fresh-cut carrot (cv. Nantes) quality as affected by abiotic stress (heat shock and UV-C irradiation) pre-treatments. LWT-Food Science and Technology, v. 48, n. 2, p. 197-203, 2012. http://dx.doi.org/10.1016/j.lwt.2012.03.013

ÁLVAREZ-VIRRUETA, D. et al. Effect of high hydrostatic pressure on postharvest physiology of the 'Ataulfo' mango. CyTA-Journal of Food, v. 10, n. 2, p. 173-181, 2012. http://dx.doi.org/10.1080/1 9476337.2011.603843

ASSOCIATION OF OFFICIAL ANALYTICAL CHEMISTS - AOAC. Official methods of analysis. 13th ed. Washington: AOAC, 1984. p. 195-417.

CANDELARIO, R. H. E. et al. Efficacy of high hydrostatic pressure as a quarantine treatment to improve the quality of mango fruits infested by the Mexican fruit fly Anastrepha ludens. CyTAJournal of Food, v. 7, n. 2, p. 135-142, 2009. http://dx.doi. org/10.1080/19476330903067953

DE ANCOS, B.; GONZÁLEZ, E.; CANO, P. Effect of high pressure treatment on the carotenoid composition and the radical scavenging activity of persimmon fruit purees. Journal of Agricultural and Food Chemistry, v. 48, n. 1, p. 3542-3548, 2000. PMid:10956147. http://dx.doi.org/10.1021/jf990911w

ELTELIB, H. A. et al. Gene expression of monodehydroascorbate reductase and dehydroascorbate reductase during fruit ripening and in response to environmental stresses in acerola (Malpighia glabra). Journal of Plant Physiology, v. 168, n. 6, p. 619-627, 2011. PMid:20933298. http://dx.doi.org/10.1016/j.jplph.2010.09.003

FERRARI, G.; MARESCA, P.; CICCARONE, R. The effects of high hydrostatic pressure on the polyphenols and anthocyanins in red fruit products. Procedia Food Science, v. 1, n. 1, p. 847-853, 2011. http://dx.doi.org/10.1016/j.profoo.2011.09.128

GRASSMANN, J.; HIPPELI, S.; ELSTNER, E. F. Plant's defence and its benefits for animal and medicine: role of phenolics and terpenoids in avoiding oxygen stress. Plant Physiology and Biochemistry, v. 40, n. 6, p. 471-478, 2002. http://dx.doi.org/10.1016/S09819428(02)01395-5

GUERRERO, J. A.; SWASON, B. G.; BARBOSA, G. V. High hydrostatic pressure processing of mango puree containing antibrowning agents. Journal of Food Science and Technology, v. 11, n. 4, p. 261-267, 2005.

KEVERS, C. et al. Evolution of antioxidant capacity during storage of selected fruits and vegetables. Journal of Agricultural and Food Chemistry, v. 55, n. 21, p. 8596-8603, 2007. PMid:17880151. http:// dx.doi.org/10.1021/jf071736j

KORHONEN, H. et al. Impact of processing on bioactive proteins and peptides. Trends Food Science and Technology, v. 9, n. 8-9, p. 307-319, 1998. http://dx.doi.org/10.1016/S0924-2244(98)00054-5
MASIBO, M.; HE, Q. Major mango polyphenols and their potential significance to human health. Comprehensive Reviews in Food Science and Food Safety, v. 7, n. 4, p. 309-318, 2008. http://dx.doi. org/10.1111/j.1541-4337.2008.00047.x

McINERNEY, J. K. et al. Effects of high pressure processing on antioxidant activity, and total carotenoid content and availability, in vegetables. Innovative Food Science and Emerging Technologies, v. 8, n. 4, p. 543-548, 2007. http://dx.doi.org/10.1016/j. ifset.2007.04.005

MENEZES, E. M. et al. Efeito da alta pressão hidrostática na atividade de enzimas da polpa de açaí. Ciência e Tecnologia de Alimentos, v. 28 , n. 1 , p. $14-19,2008$. http://dx.doi.org/10.1590/S010120612008000500003

MÉXICO. Secretaria de Agricultura, Ganadería, Desarrollo Rural, Pesca y Alumentación - SAGARPA. 2011. Disponível em: <www. sagarpa.gob.mx>.

NEVEN, L.; FOLLETT, P. A.; RAGHUBEER, E. Potential for high hydrostatic pressure processing to control quarantine insects in fruit. Journal of Economic Entomology, v. 100, n. 5, p. 14991503, 2007. http://dx.doi.org/10.1603/0022-0493(2007)100[1499:PF HHPP]2.0.CO;2

PHILIP, T.; CHEN, T. S. Development of a method for the quantitative estimation of provitamin A carotenoids in some fruits. Jorunal of Food Science. v. 53, n. 6, p. 1703-1706, 1988. http://dx.doi. org/10.1111/j.1365-2621.1988.tb07820.x

PLAZA, L. et al. Influence of ripening and astringency on carotenoid content of high-pressure treated persimmon fruit (Diospyros kaki L.). Food Chemistry, v. 130, n. 3, p. 591-597, 2012. http://dx.doi. org/10.1016/j.foodchem.2011.07.080

ROBLES-SÁNCHEZ, R. M. et al. Effect minimal processing on bioactive compounds and antioxidant activity of fresh-cut 'Kent' mango (Mangifera indica L.). Postharvest Biology and Technology, v. 51, n. 3, p. 384-390, 2009. http://dx.doi.org/10.1016/j. postharvbio.2008.09.003

SÁNCHEZ-MORENO, C.; LARRAURI, J. A.; SAURA-CALIXTO, F. A. A procedure to measure the antiradical efficiency of polyphenols. Journal of the Science of Food and Agriculture, v. 76, n. 2, p. 270-276, 1998. http://dx.doi.org/10.1002/(SICI)10970010(199802)76:2<270::AID-JSFA945>3.0.CO;2-9

SHIRLEY, B. W. Biosynthesis of flavonoids and effects of stress. Current Opinion in Plant Biology, v. 5, n. 3, p. 218-223, 2002. http://dx.doi. org/10.1016/S1369-5266(02)00256-X

SUNTORNSUK, L. et al. Quantitation of vitamin C content in herbal juice using direct titration. Journal of Pharmaceutical and Biomedical Analysis, v. 28, n. 5, p. 849-855, 2002. http://dx.doi. org/10.1016/S0731-7085(01)00661-6

TALCOTT, S. T. et al. Ripening associated phytochemical changes in mango (Mangifera indica) following thermal quarantine and lowtemperature storage. Journal of Food Science, v. 70, n. 5, p. 337341, 2005. http://dx.doi.org/10.1111/j.1365-2621.2005.tb09963.x

TANGWONGCHAI, R.; LEDWARD, D. A.; AMES, J. M. Effect of high pressure treatment on the texture of cherry tomato. Journal of Agricultural and Food Chemistry, v. 48, n. 5, p. 1434-1441, 2000. PMid:10820039. http://dx.doi.org/10.1021/jf990796p

VÁZQUEZ-GUTIÉRREZ, J. L. et al. Changes in the microstructure and location of some bioactive compounds in persimmons treated by high hydrostatic pressure. Postharvest Biology and Technology, v. 61 , n. $2-3$, p. 137-144, 2011a. http://dx.doi.org/10.1016/j. postharvbio. 2011.03 .008

VÁZQUEZ-GUTIÉRREZ, J. L. et al. Impact of high hydrostatic pressures on the structure, diffusion of soluble compounds and 
textural properties of persimmon 'Rojo Brillante'. Food Research International, v. 47 , n. 2, p. 218-222, 2011 b. http://dx.doi. org/10.1016/j.foodres.2011.06.024

VELÁZQUEZ, G. et al. An improved quarantine method for mangoes against the mexican fruit fly based on high-pressure processing combined with heat. Foodborne Pathogens and Disease, v. 7, n. 5, p. 493-498, 2010a. PMid:20001324. http://dx.doi.org/10.1089/ fpd.2009.0452

VELÁZQUEZ, G. et al. High hydrostatic pressure at low temperature as a quarantine treatment to improve the quality of fruits. Foodborne Pathogens and Disease, v. 7, n. 3, p. 287-292, $2010 \mathrm{~b}$. PMid:19899960. http://dx.doi.org/10.1089/fpd.2009.0399

VIÑA, S. Z.; CHAVES, A. R. Antioxidant responses in minimally processed celery during refrigerated storage. Food Chemistry, v. 94, n. 1, p. 68-74, 2006. http://dx.doi.org/10.1016/j. foodchem.2004.10.051
WOLBANG, C. M.; FITOS, J. L.; TREEBY, M. T. The effect of high pressure processing on nutritional value and quality attributes of Cucumis melo L. Innovative Food Science and Emerging Technologies, v. 9, n. 2, p. 196-200, 2008. http://dx.doi.org/10.1016/j. ifset.2007.08.001

WU, Z. S.; ZHANG, M.; WANG, S. Effect of high pressure argon treatments on the quality of fresh-cut apples at cold storage. Food Control, v. 23, n. 1, p. 120-127, 2012. http://dx.doi.org/10.1016/j. foodcont.2011.06.021

YONG, C. S. et al. Effect of ultra high pressure processing on immunomodulatory activities of the fruits of Rubus coreanus Miquel. Innovative Food Science and Emerging Technologies, v. 12, n. 3, p. 207-215, 2011. http://dx.doi.org/10.1016/j.ifset.2011.04.002

ZHISHEN, J.; MENGCHENG, T.; JIANMING, W. The determination of flavonoid contents in mulberry and their scavenging effects on superoxide radicals. Food Chemistry, v. 64, n. 4, p. 555-559, 1999. http://dx.doi.org/10.1016/S0308-8146(98)00102-2 